\title{
KAMPANYE KEBERSIHAN LINGKUNGAN MELALUI PROGRAM KERJA BAKTI MAHASISWA PROGRAM STUDI MANAJEMEN DI KELURAHAN POTULANDO, KECAMATAN ENDE TENGAH, KABUPATEN ENDE
}

\author{
Maria Helena Carolinda Dua Mea ${ }^{1 *}$ \\ 1 Universitas Flores, Ende, Indonesia \\ *Penulis Koresponsensi, email: helenaduamea@gmail.com
}

Article History

Received:11/11/2020

Revised:14/11/2020

Accepted:15/11/2020

\begin{abstract}
Environmental cleanliness is a vital issue in social life, especially the people of Ende Regency. To help overcome the problem of waste in community settlements, an environmental cleanliness campaign was carried out through community service activities by the academics of the Management Study Program of the University of Flores. The purpose of this community service activity with community service is to campaign for the importance of environmental cleanliness to the people of Potulando Village, Ende Tengah District, Ende Regency, help overcome environmental cleanliness problems in the Potulando Village community, train students to have a caring attitude towards nature and the environment, and make Tri Higher Education Dharma. This activity is a Community Service Activity carried out by students of the 2016 and 2017 Flores University Management Study Program. The activity was carried out in the Potulando Village area, Ende Tengah Subdistrict, Ende Regency on November 12, 2019. This environmental cleanliness campaign activity was carried out using the voluntary cleaning work method. environment and collection and sorting of waste types. Environmental cleanliness campaign activities begin with environmental cleaning activities, namely by cleaning roads from wild plants that grow on the roads and sidewalks, then cleaning the gutters from accumulated garbage. Waste sorting is carried out by sorting waste based on its type, namely organic waste and inorganic waste
\end{abstract}

Keywords: Environmental Cleanliness, Community Service

\begin{abstract}
Abstrak. Kebersihan lingkungan merupakan isu vital dalam kehidupan bermasyarakat khususnya masyarakat Kabupaten Ende. Untuk membantu mengatasi masalah sampah di pemukiman masyarakat, maka dilakukan kampanye kebersihan lingkungan melalui kegiatan kerja bakti lingkungan oleh civitas akademika Program Studi Manajemen Universitas Flores. Tujuan dari kegiatan pengabdian masyarakat dengan kerja bakti ini adalah mengkampanyekan pentingnya kebersihan lingkungan terhadap masyarakat kelurahan Potulando, Kecamatan Ende Tengah, Kabupaten Ende, membantu mengatasi permasalahan kebersihan lingkungan di masyarakat Kelurahan Potulando, melatih mahasiswa untuk memiliki sikap kepedulian terhadap alam dan lingkungan, serta mewujudkan Tri Dharma Perguruan Tinggi. Kegiatan ini merupakan Kegiatan Pengabdian Masyarakat yang dilaksanakan oleh mahasiswa Program Studi Manajemen Universitas Flores Angkatan 2016 dan 2017. Kegiatan dilaksanakan pada wilayah Kelurahan Potulando, Kecamatan Ende Tengah, Kabupaten Ende pada tanggal 12 November 2019. Kegiatan kampanye kebersihan lingkungan ini dilakukan dengan metode Kerja bakti membersihkan lingkungan serta Pengumpulan dan pemilahan jenis sampah. Kegiatan kampanye kebersihan lingkungan diawali dengan kegiatan pembersihan lingkungan, yaitu dengan melakukan pembersihan ruas jalan dari tumbuhan liar yang tumbuh di jalan maupun trotoar, lalu dilakukan pembersihan selokan-selokan dari sampah yang menumpuk. Pemilahan jenis sampah dilakukan dengan memilahkan sampah berdasarkan jenisnya yaitu sampah organik dan sampah anorganik.
\end{abstract}

Kata Kunci : Kebersihan Lingkungan, Kerja Bakti

How to Cite: Mea, M. H. C. D. (2020). KAMPANYE KEBERSIHAN LINGKUNGAN MELALUI PROGRAM KERJA BAKTI MAHASISWA PROGRAM STUDI MANAJEMEN DI KELURAHAN POTULANDO, KECAMATAN ENDE TENGAH, KABUPATEN ENDE. Mitra Mahajana: Jurnal Pengabdian Masyarakat, 1(1), 54-58. https://doi.org/10.37478/mahajana.v1i1.719.

\section{PENDAHULUAN}

Kebersihan adalah keadaan bebas dari kotoran, termasuk di antaranya, debu, sampah, dan bau. Di zaman modern, setelah Louis Pasteur menemukan proses penularan penyakit atau infeksi disebabkan oleh mikroba, kebersihan juga berarti bebas dari virus, bakteri patogen, dan bahan kimia berbahaya. Kebersihan adalah salah satu tanda dari keadaan higiene yang baik. 
Manusia perlu menjaga kebersihan lingkungan dan kebersihan diri agar sehat, tidak menyebarkan kotoran, atau menularkan kuman penyakit bagi diri sendiri maupun orang lain (Iskandar, 2018) (Shannon et al., 2018) (Khairunnisa, Ilham Syahrul Jiwandono, Nurhasanah1, Nurul Kemala Dewi, Heri Hadi Saputra, 2019).

Kebersihan lingkungan merupakan isu vital dalam kehidupan bermasyarakat khususnya masyarakat Kabupaten Ende. Perilaku masyarakat yang membuang sampah sembarangan baik di jalanan maupun di selokan-selokan mengakibatkan lingkungan menjadi kotor, dan membuat selokan tersumbat dengan sampah, yang akibatnya paling dirasakan saat musim penghujan. Pada saat musim hujan terjadi sumbatan dalam selokan yang mengakibatkan banjir di pemukiman warga. Walaupun sudah sering dilakukan himbauan terhadap masyarakat tentang pentingnya menjaga kebersihan lingkungan dan memilah sampah berdasarkan jenisnya, tetapi masalah yang sama selalu terjadi.

Ada beberapa wilayah di dalam Kota Ende yang menurut survey awal adalah wilayah dengan warga yang kurang tertib dalam pembuangan sampah rumah tangga, yakni kelurahan Mautapaga, kelurahan Paupire, kelurahan Onekore dan kelurahan Potulando. Pada umumnya warga memiliki perilaku untuk membuang sampah di dalam selokan, atau membakarnya. Hal ini tentu saja akan berdampak pada kebersihan lingkungan dan kesehatan masyarakat pada umumnya. Selain itu juga belum adanya kesadaran masyarakat untuk memilah sampah berdasarkan jenisnya yaitu sampah organik dan sampah anorganik.

Untuk membantu mengatasi masalah sampah di pemukiman masyarakat, maka dilakukan kampanye kebersihan lingkungan melalui kegiatan kerja bakti lingkungan oleh civitas akademika Program Studi Manajemen Universitas Flores. Tujuan dari kegiatan pengabdian masyarakat dengan kerja bakti ini antara lain :1)mengkampanyekan pentingnya kebersihan lingkungan terhadap masyarakat kelurahan Potulando, Kecamatan Ende Tengah, Kabupaten Ende. 2)membantu mengatasi permasalahan kebersihan lingkungan di masyarakat Kelurahan Potulando, 3)melatih mahasiswa untuk memiliki sikap kepedulian terhadap alam dan lingkungan, 4)mewujudkan Tri Dharma Perguruan Tinggi.

\section{METODE PELAKSANAAN}

Metode pelaksanaan kegiatan kampanye kebersihan lingkungan ini diuraikan sebagai berikut:

1) Jenis kegiatan

Kegiatan ini merupakan Kegiatan Pengabdian Masyarakat yang dilaksanakan oleh mahasiswa Program Studi Manajemen Universitas Flores Angkatan 2016 dan 2017.

2) Lokasi dan Waktu kegiatan

Kegiatan dilaksanakan pada wilayah Kelurahan Potulando, Kecamatan Ende Tengah, Kabupaten Ende pada tanggal 12 November 2019.

3) Agenda kegiatan Kegiatan kampanye kebersihan lingkungan ini dilakukan dengan metode sebagai berikut:

1. Kerja bakti membersihkan lingkungan

2. Pengumpulan dan pemilahan jenis sampah.

\section{HASIL DAN PEMBAHASAN}

Kegiatan pengabdian kepada masyarakat berupa kampanye kebersihan lingkungan diikuti oleh para dosen dan mahasiswa Program Studi Manajemen Angkatan 2016 dan 2017. Kegiatan dimulai sejak pukul 06.00 pagi dan dikoordinir langsung oleh para dosen pendamping. Kegiatan kampanye kebersihan lingkungan diawali dengan kegiatan pembersihan lingkungan, yaitu dengan melakukan pembersihan ruas jalan dari tumbuhan liar yang tumbuh di jalan maupun trotoar. Tumbuhan liar yang tumbuh di sepanjang jalan dan trotoar dapat mengganggu lalu lintas kendaraan dan mengganggu para pejalan kaki, selain itu tumbuhan liar yang tumbuh dapat merusak bangunan trotoar, apalagi saat musim penghujan ketika tanaman liar cenderung 55 | KAMPANYE KEBERSIHAN LINGKUNGAN MELALUI ... KECAMATAN ENDE TENGAH, KABUPATEN ENDE 
lebih cepat bertumbuh. Tumbuhan liar yang dibersihkan kemudian disatukan dan dimasukkan dalam pemilahan sampah jenis sampah organik.

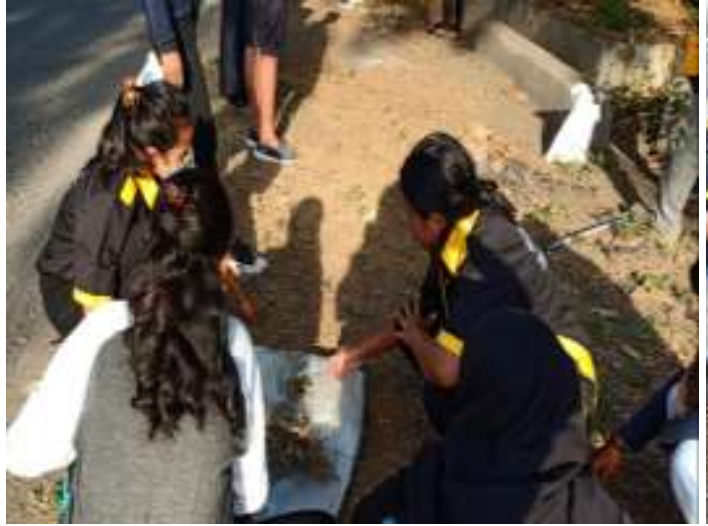

(a)

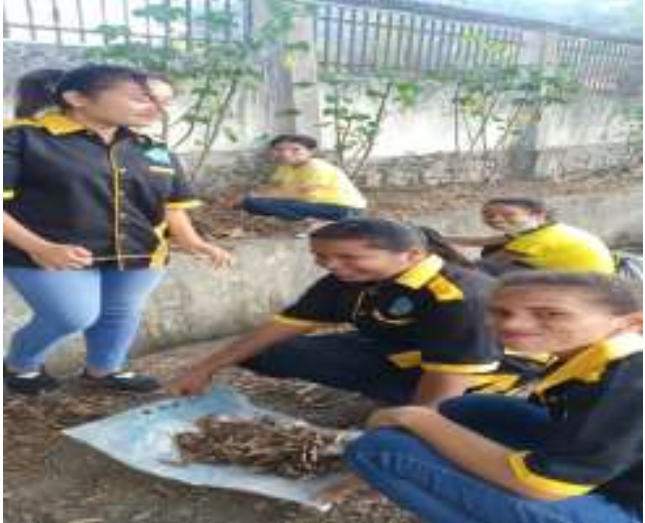

(b)

Gambar 1. Kegiatan membersihkan ruas jalan dan trotoar dari tumbuhan liar (a) Kegiatan membersihkan ruas jalan dan trotoar dari tumbuhan liar (b)

Kegiatan berikutnya adalah pembersihan selokan-selokan dari sampah yang menumpuk. Sampah yang berada di dalam selokan umumnya berasal dari daun kering dari pepohonan di jalan dan sampah rumah tangga terdiri dari limbah plastik dan kemasan makanan serta minuman. Sampah yang menumpuk di selokan akan menyebabkan tersumbatnya saluran air sehingga terjadi luapan air keluar jalan umum. Tidak adanya layanan pengangkutann sampah seminggu sekali menyebabkan warga membuang sampah di selokan.

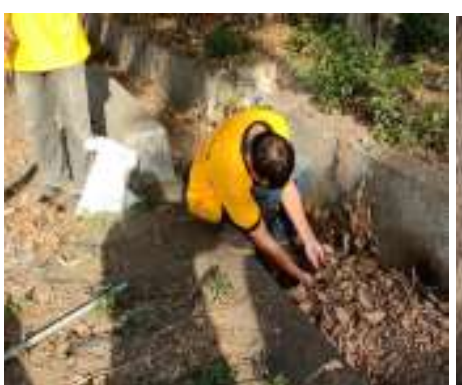

(a)

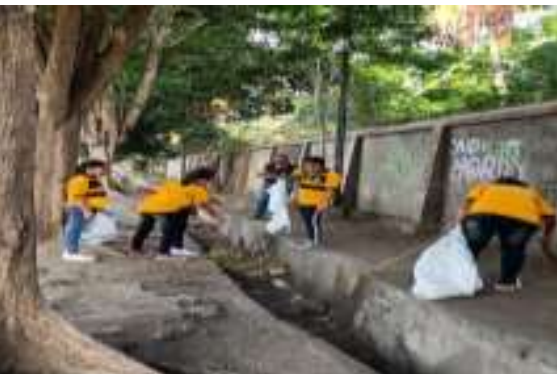

(b)

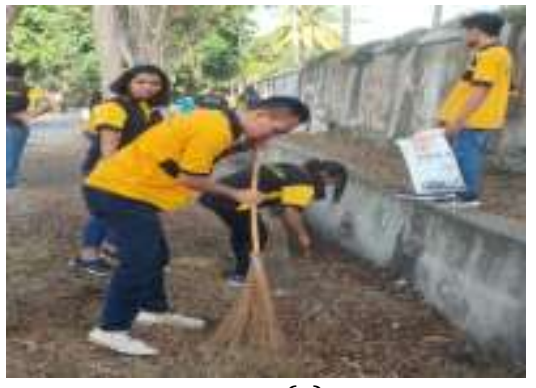

(c)

Gambar 2. Kegiatan membersihkan selokan dari tumpukan sampah organik

Kegiatan terakhir dalam kampanye kebersihan lingkungan ini adalah pemilahan sampah berdasarkan jenisnya. Pemilahan jenis sampah dilakukan dengan memilahkan sampah berdasarkan jenisnya yaitu sampah organik dan sampah anorganik. Sampah organic berupa dedaunan kering, ranting kering, serta sisa-sisa pengolahan makanan di rumah tangga. Sampah organik ini dapat dikumpulkan untuk dijadikan pupuk dengan metode fermentasi (pembusukan). Pupuk yang dihasilkan dari sampah organik merupakan pupuk bebas bahan kimia, ramah lingkungan dan aman bagi ekosistem lingkungan hidup.

Sampah anorganik berupa sampah plastik seperti kemasan air mineral, kemasan minuman, kertas, dan tas plastik. Sampah anorganik ini dikumpulkan mahasiswa dan kemudian diserahkan kepada petugas kebersihan Kota Ende untuk dibawa ke tempat pembuangan sampah. Pada kegiatan ini juga dilakukan sosialisasi bagi masyarakat untuk tidak membakar sampah plastik karena akan mengakibatkan polusi udara dari asap yang dihasilkan, selain itu juga endapan pembakaran plastik akan berpengaruh pada kualitas tanah dan air tanah. 


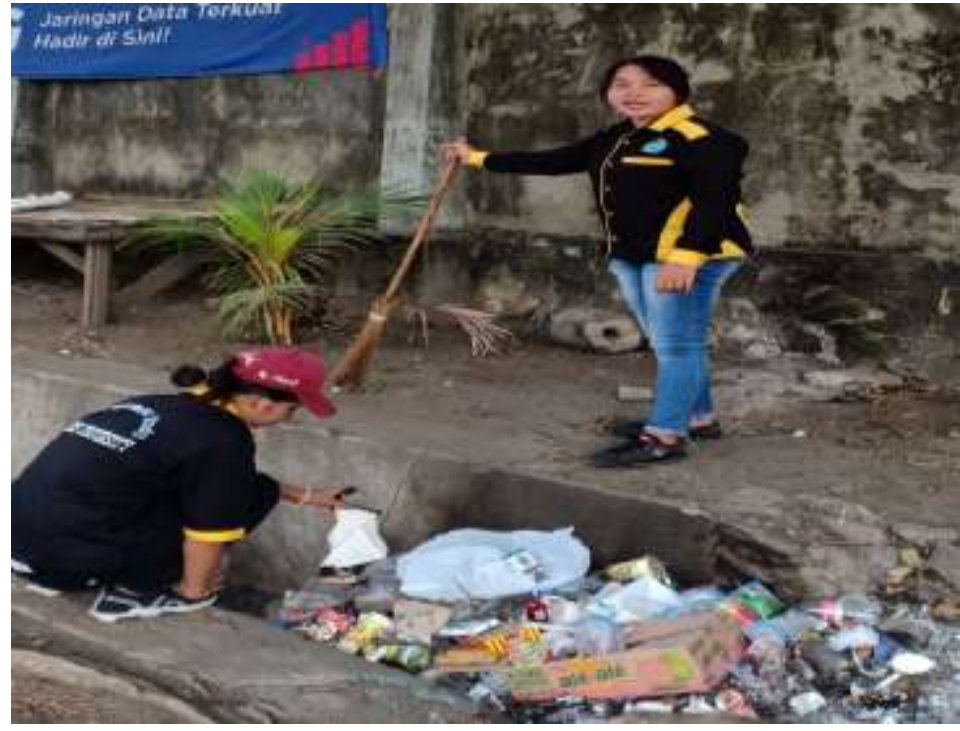

Gambar 3. Kegiatan mengumpulkan dan memilah sampah anorganik

Setelah dilakukan kerja bakti dan dan sosialisasi pemilahan sampah kepada masyarakat, maka lingkungan Kelurahan Potulando menjadi lebih bersih dan sehat. Lingkungan yang bersih akan mencegah penyakit dan berkontribusi dalam perbaikan kualitas Kesehatan masyarakat seperti yang disampaikan oleh Iskandar (2018) dan (Khairunnisa, Ilham Syahrul Jiwandono, Nurhasanah1, Nurul Kemala Dewi, Heri Hadi Saputra, 2019). Setelah melakukan tiga kegiatan diatas, masyarakat Kelurahan Potulando akhirnya mengetahui bahwa kebersihan lingkungan akan menciptakan lingkungan yang bersih, nyaman, dan asri. Gerakan kebersihan dapat dilakukan di mana saja seperti di lingkungan sekitar maupun di tempat umum lainnya sehingga masyarakat yang berada di tempat tersebut akan merasa nyaman dengan lingkungan yang bersih. Masyarakat pada akhirnya akan memahami bahwa melaksanakan hidup bersih sangat penting untuk dilakukan.

\section{SIMPULAN DAN TINDAK LANJUT}

Secara umum kegiatan pengabdian kepada masyarakat dalam bentuk kampanye kebersihan lingkungan ini berjalan dengan lancar. Kegiatan demi kegiatan dapat berjalan dengan baik dan mendapat dukungan penuh dari sebagian besar masyarakat. Pengabdian kepada masyarakat ini telah berhasil mencapai tujuan utama yaitu meningkatkan kesadaran masyarakat Kelurahan Potulando terhadap kebersihan dan Kesehatan lingkungan. Setelah pengabdian selesai, diharapkan tingkat kepedulian sebagian besar masyarakat terhadap kebersihan dan kesehatan lingkungan mulai meningkat.

Permasalahan kebersihan lingkungan selalu berkaitan dengan kesehatan masyarakat. Perilaku masyarakat menjadi hal utama yang harus diperhatikan oleh pemerintah jika ingin mensosialisasikan atau mengkampanyekan gerakan kebersihan bagi masyarakat, khususnya masyarakat Kota Ende yang belum memiliki kesadaran untuk memperlakukan sampah rumah tangga sebagaimana mestinya. Diharapkan dengan adanya kegiatan pengabdian masyarakat berupa kerja bakti dan pemilahan sampah, masyarakat Kelurahan Potulando ikut tergerak untuk memiliki motivasi untuk menjaga kebersihan lingkungan sekaligus memiliki kesadaran dan pengetahuan mengenai jenis-jenis sampah. Kampanye kebersihan lingkungan diharapkan menjadi kegiatan yang memiliki keberlanjutan dengan tambahan kegiatan seperti workshop daur ulang sampah plastik.

Beberapa hal yang dapat direkomendasikan dan dapat ditindaklanjuti dari kegiatan ini adalah sebagai berikut: 
1) Kegiatan kebersihan lingkungan dalam bentuk kerja bakti hendaknya dilakukan berkesinambungan.

2) Diperlukan komitmen semua pihak dalam menjaga kebersihan lingkungan, baik pemerintah, masyarakat, maupun institusi pendidikan.

3) Diperlukan pendampingan kepada masyarakat dalam pengelolaan sampah rumah tangga.

4) Peran pemerintah sangat penting dalam rangka melanjutkan kegiatan yang sejenis. Diperlukan program-program yang lain yang berhubungan dengan kebersihan lingkungan.

\section{DAFTAR PUSTAKA}

Khairunnisa, Ilham Syahrul Jiwandono, Nurhasanah1, Nurul Kemala Dewi, Heri Hadi Saputra, T. L. W. (2019). Kampanye Kebersihan Lingkungan Melalui Program Kerja Bakti Membangun Desa Di Lombok Utara. Jurnal Pendidikan Dan Pengabdian Masyarakat.

Memelihara Kebersihan Dan Keamanan, P., \& Arifuddin Iskandar, A. (2018). PENTINGNYA MEMELIHARA KEBERSIHAN DAN KEAMANAN LINGKUNGAN SECARAPARTISIPATIF DEMI MENINGKATKAN GOTONG ROYONG DAN KUALITAS HIDUP WARGA Andi Arifuddin Iskanda. In Jurnal Ilmiah Pena.

Shannon, C. E., Indira, T., Somakim, S., Susanty, E., Alamiah, U. S., Afriansyah, E. A., R, H. Y., Waluya, S. B., Rosita, C. D., Nopriana, T., Silvia, I., Shodiqin, A., Zuhri, M. S., Lestari, D., Rizqi, A. A., Hodiyanto, H., C.E. Shannon , vol. 27, pp. , July, October, " ", Mahardhikawati, E., Mardiyana, ... Rusmawati, R. D. (2018). Pentingnya memelihara kebersihan dan keamanan lingkungan secara partisipatif demi meningkatkan gotong royong dan kualitas hidup warga. Mathematics Education Journal.

Zainuddin, Z., Dewantara, D., Wati, M., Misbah, M., Suyidno, S., Haryandi, S., Rahmattulah, P., \& Munir, M. J. M. (2019). Pelatihan dan pendampingan penyusunan proposal penelitian tindakan kelas (PTK) bagi guru-guru IPA di kabupaten Hulu Sungai Tengah. Bubungan Tinggi Jurnal Pengabdian Masyarakat, 1(2), 79-84. 